\title{
12 Four pieces by Percy Grainger and Charles Ives
}

The four pieces featured in this chapter were written towards the beginning of the twentieth century by two composers who eschewed convention. Neither of them followed the usual path of a professional composer and each of the pieces is unusual and highly individual in its own way. There are two pieces evoking a train journey - Percy Grainger's Train Music and The Celestial Railroad by Charles Ives along with two pieces which are centered on train stations. 'Arrival Platform Humlet' was described by Grainger as 'The sort of thing one hums to oneself' whilst waiting on a station platform whereas 'From Hanover Square North, at the End of a Tragic Day, the Voices of the People Again Arose' recalls Ives' experience at a station the day that the news broke of the sinking of the RMS Lusitania.

\section{Percy Grainger (1882-1961)}

Percy Grainger is best known for his light music, notably Handel in the Strand, Shepherd's Hey, Molly on the Shore and Country Gardens which became a huge hit as In An English Country Garden. During his lifetime he was also renowned as a virtuoso pianist. But there was much more to him than his reputation as a celebrity pianist and a composer of light music. He was also a pioneering folksong collector and arranger, and an avant-garde thinker and experimentalist who worked with electronic music and instruments as early as 1937.

He was born in Melbourne, Australia, and was educated at home by his mother Rose an unorthodox creative spirit and a dominant influence on his life. As a talented young pianist he studied music in Frankfurt and then moved to 
London to further his career as a concert pianist. Whilst in England he set out to collect and record folk songs with the Edison Phonograph, one of the first folk song collectors to do so. At the outbreak of World War I, he migrated to America and eventually settled in White Plains, New York where he earnt a fortune as a pianist; during the 1920s he earnt the equivalent of $£ 50,000$ per week.

Grainger was very close to his mother, some thought abnormally so, and after her suicide in 1922 when she jumped from the 18th floor of a New York sky scraper, he gave up his performing career for a time. In 1928 he married his Swedish girlfriend Ella Ström during a Hollywood Bowl concert featuring the première of his cantata To a Nordic Princess (1927-8) and with an audience of around 20,000.

It would be an understatement to describe him as a colourful and unconventional character. He dressed in multi-coloured home-made outfits and, bursting with energy, had a habit of leaping about and jogging from one concert venue to the next with a heavy rucksack on his back. He was fluent in 11 languages including Icelandic and Russian, but substituted Italian and

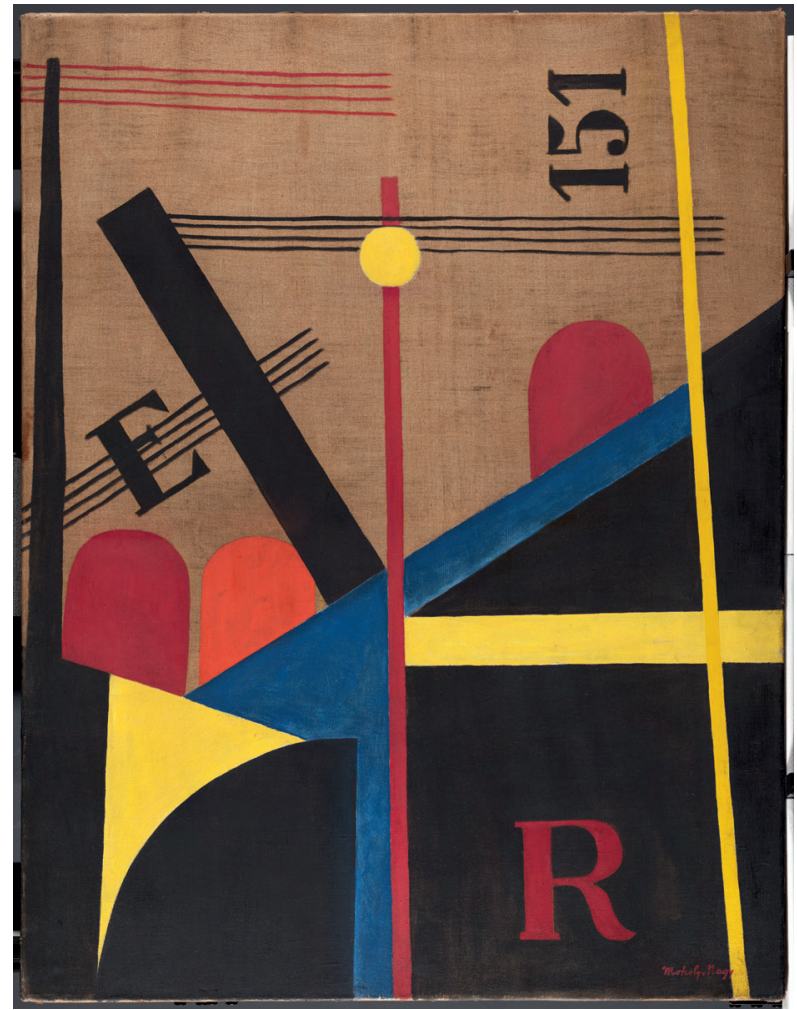

Large Railway Painting, 1920. Laszlo Moholy Nagy (1895-1946)

(C) Según indicaciones de los Titulares/ Entidad de Gestión de los derechos. Procedencia. Museo Nacional ThyssenBornemisza, Madrid 
German musical terms with Anglo-Saxon ones such as 'louden' rather than 'crescendo', and 'feelingly' instead of 'expressivo'. A charismatic personality, Grainger counted the composers George Gershwin, Duke Ellington, Edvard Grieg, and Frederick Delius amongst his friends. He died in White Plains Hospital in 1961 aged 78. In the 1930s he had established the Grainger Museum at the University of Melbourne - a repository of items documenting his life, career and music. He requested that after his death his skeleton should be placed on display there. His request was denied.

His musical output is enormous with many works having been 'dished up', as Grainger put it, for different combinations of instruments which included such rarities as the solovox ${ }^{1}$ and theremin ${ }^{2}$. He also invented some of his own including the Butterfly Piano which had microtonal tuning producing a gliding sound. He composed in a broad spectrum of styles from highly experimental works such as Free Music no. 2 for six theremins, to popular pieces such as his wind band setting of Lincolnshire Posy which he described as a "bunch of musical wildflowers'. One of his preoccupations was his vision of 'free music' and he believed that for music to be completely 'free' it needed to be released from the 'tyranny of the performer'. To this end he worked towards the elimination of human intervention in performance by developing several 'free music' machines including the Kangaroo-Pouch Tone-Tool. ${ }^{3}$

\section{Train Music}

The vast majority of his compositions are for piano and much of it is very difficult to play. Grainger had very large hands and his piano music often uses a wide span. About 20 of the piano pieces are 'fragments' of projected series giving only the main theme of the work. Train Music is one such fragment. It exists in two versions - some sketches for large orchestra lasting less than five minutes, and a simplified piano version which lasts not much longer than 30 seconds. The pieces are rarely performed but there are several recordings available.

Grainger's mother accompanied her son on an extended European tour in the summer of 1900 and Train Music is his response to their travel in a very jerky train going from Genova to San Remo' (roughly 150 miles). The GenovaVentimiglia railway was completed as a single track line in 1872 . It is a scenic 
route often running close to the sea in the Liguria region of Italy. He started work on the piece when he was 18 and then played with the idea over the years making further jottings on the long railway journeys that he was partial to where he loved to spread his manuscripts out and compose.

Train Music is characterised by frequent changes of time signature and big percussive chords. This style of music was at odds with the prevailing romanticism of the time. With what Grainger referred to as its irregular barring, and its predominantly rhythmic texture and dissonant chords, it had more in common with Stravinsky's ground-breaking orchestral piece Rite of Spring (1913). Overall the effect is one of an alarming sense of rhythmic dislocation.' According to Grainger-expert Bryan Fairfax,

Train Music was born of a desire for a music to be created not only out of the sounds and rhythms of a moving train, but of its smell, heat, material, invincible 'onward rushing' (Grainger's words), changes of scene, climate and weather en route, heroic non-complaining in the service of mankind, and its consummate weight when at rest. A glorious totality; an essence transmuted into sound. ${ }^{5}$

The orchestral version is for 150 players, an orchestra of gargantuan proportions, and the equivalent of two symphony orchestras. There are parts for 100 strings and a massive woodwind section of 38 players rather than the usual number of eight players. They are mostly double reeds (eight oboes, four cor Anglais, six bassoons and two double bassoons) resulting in a strong nasal sound. The orchestral version was never realizable because of the large number of instruments needed but the fragment of the score was completed with a reduced orchestration in 1976 by Eldon Rathburn and can be found in the Grainger Archives.

\section{'Arrival Platform Humlet'}

'Arrival Platform Humlet' is the first movement of Grainger's four-movement suite In a Nutshell. It was put together from various pieces written at different times.

1. Arrival Platform Humlet

2. Gay but wistful

3. Pastoral

4. The Gum-suckers March 
The movement 'Arrival Platform Humlet' exists in several versions - for solo piano, two pianos, solo viola or 'massed violas', along with a version for piano and orchestra with multiple tuned and untuned percussion instruments. The viola version is described as being for 'middle fiddle' owing to Grainger's aversion to the use of Italian terms in music. In Grainger's own words written at the top of the score, the piece was 'begun in Liverpool Street and Victoria Stations, London (England) on February 2, 1908' and 'scored for orchestra, piano and Deagan percussion instruments ${ }^{6}$ as the first movement of my suite "In a Nutshell." The musicologist Wilfrid Mellers describes it as a very odd piece that only Grainger could have thought up. At the top of the score Grainger writes

Awaiting the arrival of a belated train bringing one's sweetheart from foreign parts: great fun! The sort of thing one hums to oneself as an accompaniment to one's tramping feet as one happily, excitedly, paces up and down the arrival platform. The final swirl does not depict the incoming of the expected train. The humlet is not programme music in any sense. It is marching music composed in an exultant mood in a railway station, but does not portray the station itself, its contents, or any event.

At this time of his life the 'sweetheart from foreign parts' may well have been his then lover and later long-time friend, the Danish pianist Karen Holten (1879-1953).

Grainger would mark his scores with idiosyncratic directions for the performers. The opening of 'Arrival Platform Humlet' is marked 'with healthy and somewhat fierce "go", 'fierce' being a characteristic quality 'much admired' by Grainger. The opening woodwind theme of the orchestral version is marked 'nasal, reedy and snarling', a tone quality that classical woodwind players are more likely to avoid. Performance directions instruct the performers to play 'more clingingly' then 'less clingingly' and finally 'very clingingly'. The piece is mainly in octaves and unisons with no definite key and no predetermined form, rather it has the effect of spontaneous humming with snippets of tune strung together as they occur to the hummer, with little repetition'. In Grainger's words

There are next to no chords in this composition, it being conceived almost exclusively in single line (unaccompanied unison or octave). There are likewise no 'themes' (in the sense of often-repeated motives), as the movement from start to finish is just an unbroken stretch of constantly varied melody with very few repetitions of any of its phrases. 
These elements of 'free music' risked the piece lacking direction. However, towards its end, the command 'louden lots' moves towards an exciting conclusion marked by two chords to be played very loudly 'All you can'.

\section{Charles Ives (1874-1954)}

Charles Ives is now regarded by many as the leading American composer of the early twentieth century. Like Grainger, he too was a maverick and had an extraordinary working life. Although he studied music at Yale, composed and held various positions as a church organist, Ives did not pursue a professional career in music. Instead, in order to provide for his family, he opted for the more reliable insurance industry where he was very successful. So successful that after 20 years his company became the largest insurance agency in the country and he was soon a millionaire. He led a sort of double life where he composed in his free time and managed to create an immense body of music, even though he was only composing at weekends and on holidays. Inevitably he created his music in isolation which resulted in a highly original body of work in a wide variety of styles, from tonal Romanticism to radical experimentation, often embracing different stylistic characteristics within a single work, from atonality to polytonality, ragtime to ametrical rhythm. At the same time he drew on the music that he had grown up with such as popular American songs, parlour ballads, patriotic songs and hymn tunes, often quoting these within his pieces.

His works include symphonies and other orchestral works, amongst them the powerfully evocative piece The unanswered question and Three places in New England (also known as Orchestral set no. 1) where in one movement the conductor has to beat different times with each arm to represent the sound of overlapping bands marching, something which he had experienced when he was young. There are two piano sonatas, the second being the fearfully difficult Concord sonata where the movements are dedicated to important American writers - 'Emerson', 'Hawthorne', 'The Alcotts' and 'Thoreau'.

Ives worked in insurance for 30 years after which he devoted much of his time to revising his musical output and promoting its performance. He waited many years for recognition, partly because of the complexity of much of his music, partly because much of it had not been published, but after his death in 
New York City in 1954, his reputation grew and his music eventually became a firm part of the concert repertoire.

\section{'From Hanover Square North, at the End of a Tragic Day, the Voices of the People Again Arose'}

Ives spent his summers in Redding, Connecticut and would commute every day to his job in New York over 60 miles away. It was a long haul, at least two hours between Redding and Grand Central Station. The journey started with a steam locomotive taking passengers down a single-track line and ended with the Third Avenue 'L' to Hanover Square, an elevated line in Manhattan.

'From Hanover Square North' is the third movement of the Orchestral Set No. 2 which Ives assembled from material that he had composed between about 1909 and 1919 (although the first performance was not until 1967). The opening movement is 'An elegy to our forefathers' and the second movement is 'The Rockstrewn Hills join in the people's outdoor meeting'. The piece is scored for large orchestra which includes some instruments not normally found in this setting such as tuba, harpsichord, accordion, two pianos and two theremins. 'From Hanover Square North' adds a distant choir to the mix. It quotes several melodies that are well known in America: 'Massa's in de cold ground'; 'Ewing'; and 'My Old Kentucky home', but it is the hymn 'In the sweet bye and bye' (sometimes spelt as 'In the sweet by and by') that is central to the piece.
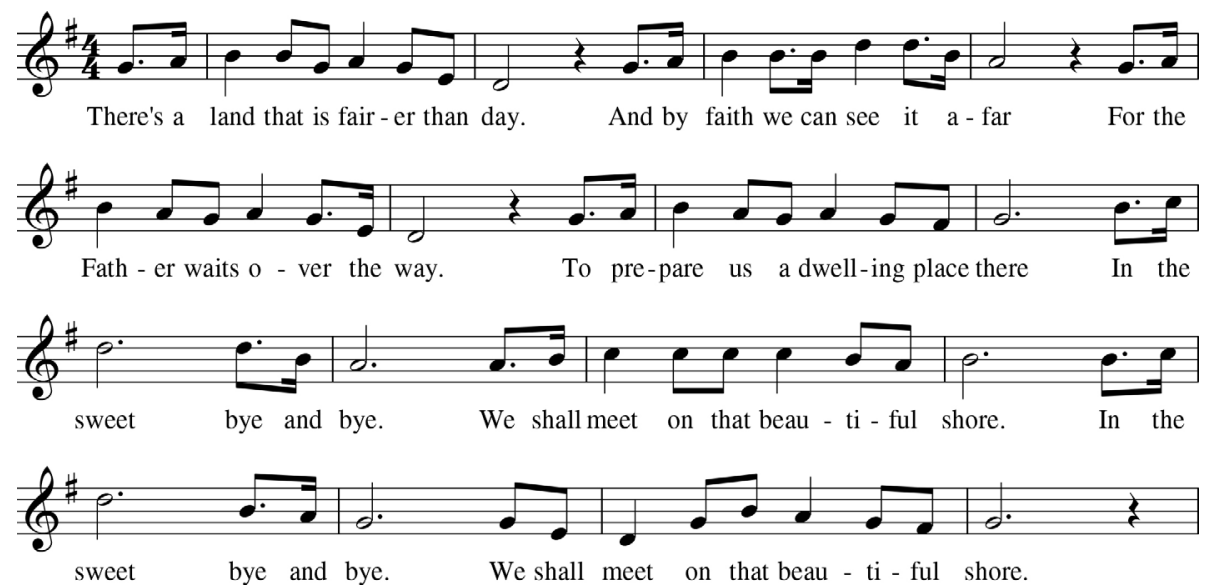
Ives recounted the origins of 'From Hanover Square North' in his Memos.

We were living in an apartment at 27 West 11 th Street. The morning paper on the breakfast table gave the news of the sinking of the Lusitania. I remember, going downtown to business, the people on the streets and on the elevated train had something in their faces that was not the usual something. Everybody who came into the office, whether they spoke about the disaster or not, showed a realization of seriously experiencing something. (That it meant war is what the faces said, if the tongues didn't.) Leaving the office and going uptown about 6 o'clock, I took the Third Avenue "L" at the Hanover Square Station. As I came on the platform, there was quite a crowd waiting for the trains, which had been blocked lower down, and while waiting there, a hand-organ, or hurdy gurdy was playing on a street below. Some workmen sitting on the side of the tracks began to whistle the tune, and others began to sing or hum the refrain. A workman with a shovel over his shoulder came on the platform and joined in the chorus, and the next man, a Wall Street banker with white spats and a cane, joined in it, and finally it seemed to me that everybody was singing this tune, and they didn't seem to be singing for fun, but as a natural outlet for what their feelings had been going through all day long. There was a feeling of dignity all through this. The hand-organ man seemed to sense this and wheeled the organ nearer the platform and kept it up fortissimo (and the chorus sounded out as though every man in New York must be joining in it). Then the first train came and everybody crowded in, and the song eventually died out, but the effect on the crowd still showed. Almost nobody talked-the people acted as though they might be coming out of a church service. In going uptown, occasionally little groups would start singing or humming the tune. ${ }^{8}$

Now what was the tune? It wasn't a Broadway hit, it wasn't a musical comedy air, it wasn't a waltz tune or a dance tune or an opera tune or a classical tune, or a tune that all of them probably knew. It was (only) the refrain of an old Gospel Hymn that had stirred many people of past generations. It was nothing but-"In the sweet bye and bye." It wasn't a tune written to be sold, or written by a professor of music--but by a man who was but giving out an experience.

This third movement is based on this, fundamentally, and comes from that "L" station. It has secondary themes and rhythms, but widely related, and its general makeup would reflect the sense of many people living, working, and occasionally going through the same deep experience, together...

The city noises of New York are represented by background ostinato. Over these dissonant sounds the orchestra takes up 'In the sweet by and by'. Both 
the verse and chorus are sung, but the hymn is fragmented, with strands of its tune trailing off with other melodies encroaching. The different layers create an increasingly dense and dissonant web as the tension builds up leading to a sudden release in a direct and heartfelt statement of the hymn's chorus. The song gradually trails away as the people leave and the piece ends.

\section{The Celestial Railroad}

The Celestial Railroad is a piece for solo piano, first performed in 1928. It is based on a short story of the same name by the American author Nathaniel Hawthorne. Hawthorne's story is in itself a parody of Bunyan's Pilgrim's Progress which tells of a Christian's spiritual journey through life. In Hawthorne's version a group of train passengers follow the route of Bunyan's Christian.

The story opens with a narrator who falls asleep and dreams that he is at a depot in the City of Destruction where he is befriended by Mr Smooth-itaway who takes him to board a waiting train bound for the Celestial City. The train sets off with its whistle blowing, stopping at the town of Vanity Fair, coming to rest at Beulah Land where the passengers are told to board a ferry which will take them across the River Jordan to the Celestial City. Once they are aboard the ferry the narrator sees the duplicitous $\mathrm{Mr}$ Smooth-it-away who has now changed back into his true devilish form. He realises that it has all been a hoax and jumps into the river to escape. This wakes him up, it was only a dream.

The Celestial Railroad is a complex piece which is very demanding to play; in fact Ives gives the performer alternative strategies for some of the most difficult passages. As in many of Ives' works the music includes references to hymn tunes and popular American songs. There are snatches of 'De Camptown Races' and 'Yankee Doodle', for example, but these are usually well-hidden and give only short bursts of the melody. Ives' work is a musical depiction of Hawthorne's story and, as such, follows the same course, even including some musical representations of train sounds. It opens with rapid flourishes swirling across the piano followed by a series of high bell-like chords suggesting the train whistle blowing as the passengers arrive at the depot. The train sets off and the chugging is represented by low cluster chords which get increasingly faster as the train accelerates. 
This chapter has drawn together four differing pieces of railway music. In Train music and The Celestial Railroad both Grainger and Ives are drawn to the evocative sounds of a train journey. Both use percussive dissonant chords and a dense rhythmic texture to portray the movement of the train but Ives goes further in his imitation of train sounds whereas Grainger attempts to capture the smell, the heat, the onward rushing and the changes of scene in 'A glorious totality; an essence transmuted into sound'. Grainger's 'Arrival Platform Humlet' and Ives' 'From Hanover Square North' are both set on station platforms but they represent two very different experiences. Grainger's is a private affair where a lover hums to himself as he awaits his sweetheart, a single wandering line with no real themes or sense of direction. In contrast Ives represents a collective and intense experience where the dissonant tension of the music builds up throughout the movement until the crowd of passengers join together in a heartfelt rendition of the hymn tune 'In the sweet by and by'.

\section{Endnotes}

1 Grainger wrote for the solovox, an electronic sound-producing attachment which he added to the piano or Hammond organ.

2 A theremin is an electronic musical instrument controlled without physical contact by the player. It has two antennae, a vertical one which controls the pitch and a horizontal loop which controls the volume. Both are manipulated by the player's hands. It is named after the Russian Leon Theremin who invented it in 1920.

3 Kangaroo-Pouch Tone-Tool was developed by Grainger and the physicist Burnett Cross. It uses rolls of paper and a series of oscillators to produce a sound.

4 Wilfrid Mellers. Percy Grainger. (Oxford: Oxford University Press. 1992): 139.

5 Lewis Foreman, ed. The Percy Grainger Companion. (London: Thames Publishing. 1991): 71.

6 'Deagan percussion instruments' were manufactured by the Deagan company, founded in 1880. It manufactured glockenspiels and developed other instruments including the xylophone, vibraharp, aluminium chimes, aluminium harp, Swiss handbells, the marimba and tubular bells.

7 Mellers, Percy Grainger, 39.

8 Charles E Ives. Charles E Ives. Memos. (New York: W. W. Norton \& Company, edited by John Kirkpatrick, 1972): 92. 